\title{
Technological and Efficiency Change on Zakat Organization: Evidence in Indonesia
}

\author{
Aam Slamet Rusydiana \\ Shariah Economic Applied Research \& Training (SMART) Indonesia \\ Tika Widiastuti \\ Department of Islamic Economics, Airlangga University \\ Paper to be presented at International Conference of Zakat 2018 \\ 15-16 November, Universitas Gadjah Mada, Yogyakarta, Indonesia
}

\section{ABSTRACT}

Zakah institution is the intermediary organizations based on social. Although based on social activities, but the management is still needs to uphold professional, accountability and transparency principles. This study attempts to analyze the productivity level of zakat organization in Indonesia, both in terms of changes of its efficiency and also its technological. There are two things that are calculated in Malmquist index measurement that is catch-up effect and frontier shift effect. The catch-up effect measures the rate of change in relative efficiency from period 1 to period 2. Meanwhile the frontier shift effect measures the rate of technological change that is a combination of input and output from period 1 to period 2. The frontier shift effect is often called an innovation effect. Findings from the results of the productivity index analysis are very interesting. In general, there has been an increase in the level of productivity of zakat institutions in Indonesia in the period 2011 to 2016. The increase in productivity growth (1.116) of zakat institutions in Indonesia is generally caused by technological change (1.137) instead of changes in efficiency (0.982). Thus the service of zakat institutions is needed which is more innovative in relation to the development of technology in the future.

Keywords: Technological change, Efficiency change, Productivity, Malmquist Index, Zakat organization

\section{INTRODUCTION}

Islamic economics has spread and developed in the world. The Islamic economics and finance industry, being an object of study that is always interesting to be studied. Especially if compared with the conditions of the conventional financial industry that has already existed. For example, the results of research conducted by Nurfalah etal (2018) which states that Islamic banking is relatively more stable compared to conventional banking in the face of shock both internally and externally. This is an interesting finding that needs to be proven through various research in the future. In addition to the financial industry such as Islamic banks, Islamic insurance, sharia pawnshops and so on, Islamic finance is also known as a social financial entity that also has an equally important role. One of the instruments of Islamic social finance is zakat.

Zakat is a stimulus in the economy which raises new force in the accumulation of a significant investment that would boost 
the production of the economy cycle in the region. Zakat has a main role in the creation of justice in the economic field, in which all citizens have a source of revenue and income to fulfill daily needs for their life. In management of the use of zakat funds, the most important is the role of amil zakat (read: Zakat Institution) as bearers of the trust in management of the zakat funds. If the amil zakat is good in its management, then eight of zakat receipts (ashnaf) will be good anyway. But if the amil zakat is not good in its management, it should not be expected to ashnaf will be good too, that is essence of the amil zakat strategic (Rusydiana, 2016).

Zakat Institution (OPZ) is the intermediary organizations based on social. The entire of operating expense is taken from the zakat and infaq funds collected. It is also justified by Sharia, because OPZ committee is Amilin zakat that also included in eight ashnaf eligible for Zakat. The portion used for operation activities and Amilin's salaries (Akbar, 2009). Although OPZ based on social, but the management still needs to uphold professional, accountability, and transparency principles. Include in this term, OPZ need to operate effectively and efficiently.

Most recently, in the measurement of the effectiveness of zakat management, Baznas in cooperation with Bank Indonesia initiate the concept of Zakat Core Principles (Beik et al, 2014). So, it is necessary to measure the performance of zakat institution to find out how efficient and productive the performance of a zakat institution. Determination of the limiting factor into a benchmark whether a company has worked efficiently and productively, are separate problems. Not necessarily the factor chosen as a variable to measure the level of efficiency it represents the whole aspect of the company, in this case the zakat institution. For that we need a measurement formulation of efficiency and productivity level that can involve multi-variable.

In the world of efficiency measurement, currently widely known as Data Envelopment Analysis or DEA approach. DEA is a tool that can be used to measure and compare the performance of a number of service units or business units such as banks, financial industries, hospitals and even educational institutions. DEA may also indicate the inefficiency specifications of the service unit.

Since the DEA method was first introduced by Charnes, Cooper and Rhodes in 1978, researchers in some areas recognize that DEA is an excellent method and relatively easy to use in the operational modeling process for performance evaluation. In this study, DEA is used as a tool to measure, analyze and compare the performance of zakat institutions in this case 4 biggest zakat institutions in Indonesia for 2011-2016 periods.

Furthermore, to measure and calculate the productivity of zakat institutions observed, this study used Malmquist Productivity Index (MPI) analysis. Malmquist index is part of the DEA method that specifically looks at productivity level of each business unit, so that it will see a change in the efficiency and technology levels used based on predetermined inputs and outputs. The Malmquist index is also used to analyze intertemporal performance changes.

\section{LITERATURE REVIEW}

Efficiency and productivity is a concept that shows the ratio of the result of comparison between input and output. Both ratios show that efficiency and productivity can be controlled by manipulating input and output management, or even both simultaneously. Efficiency and also 
productivity can be used to measure the performance of a unit of economic activity.

In measuring the degree of efficiency and productivity, Data Envelopment Analysis (DEA) is preferable. DEA is widely used to measure the level of technical efficiency, scale of economic and industrial banks and financial institutions. This is suitable according to research of Kamarudin, et.al (2008); Ozdemir (2013); Shahreki (2012); Tsolas and Dimitris (2012).

An activity can be called efficient if theeffort has been done to provide maximum output, both quantity and quality. An activity can also be said to be efficient if the minimum effort can achieve a certain output. Oscar (2008) divides efficiency into several parts, namely: technical efficiency, scale efficiency, cost efficiency and also allocation efficiency. Technical efficiency is the process of converting inputs into outputs. This concept applies only to internal technical relationships between inputs and outputs. A company is considered to be economically efficient if it can minimize the production costs to produce certain output within common technology level and market price level (Farrell, 1957, Ramanthan, 2003).

Scale efficiency is associated with achieving the economies of scale of the unit in carrying out its operations. Inefficient on a scale can only be overcome by adopting new technologies or production processes. On the other hand, technical efficiency is a managerial problem, where more output is required for a given number of resources.

However, we must understand that technological differences can create economies of scale in the production process. Economies of scale are terms used to explain the decrease in cost per unit due to the addition of units produced. In a microeconomics, economies of scale are cost savings that companies earn when expanding. Measurement of efficiency can also be assessed using price information or input and / or output costs. This notion is commonly known as the concept of cost efficiency. Meanwhile, the allocation efficiency is related to how to combine various inputs to be able to produce maximum output. If there is more than one input or output, management will be interested in using the proper input mix to maximize the results so that the organization can be efficient.

The discussion is whether the use of various inputs in the calculation of efficiency is appropriate. Is it necessary to weight the use of inputs based on their contribution to output. This weighting is not available, but at least DEA can estimate this weighting in comparative evaluation. In its development, the frontier efficiency measurement model has increased, both in theory and practice concepts. In general, the efficiency and productivity level measurement model is divided into two parts: parametric and nonparametric.

The concept of productivity is basically a relationship between output and input in a production process. Productivity can be measured partially or totally. Partial productivity is the relationship between output with one input. Examples of commonly used partial productivity are labor productivity which shows the average output per worker, as well as the capital productivity that describes the average output per capital.

Total productivity or so-called Total Factor Productivity (TFP) measures the relationship between outputs with multiple inputs simultaneously. The relationship is expressed in the ratio of the output index to the aggregate input index. If the increased ratio means more output can be produced using a certain number of inputs, or some output can be produced using fewer inputs. 
In productivity measurement, the most widely used is the total factor productivity (TFP) method. This method is used to overcome the weakness of efficiency calculation more than one input and one output. TFP is measured using index numbers that can measure changes in price and quantity over time. In addition, TFP also measures comparisons and differences between entities.

The TFP $a b$ index measures the change in the output value of the selected $\mathrm{N}$ number from period "a" to " $b$ " where $p$ represents the output price. Commonly used indices for measuring TFP are Malmquist Index, Laspeyres Index, Pasche Index,Fisher Index and Tornqvist Index. In this study, which will be used to calculate the productivity level is the Malmquist Index. The Malmquist index was first created by Sten Malmquist in 1953 to measure productivity level of firms. But in its development, Malmquist Index was first introduced by Caves et.al (1982).

There are two things that are calculated in Malmquist index measurement that is catch-up effect and frontier shift effect. The catch-up effect measures the rate of change in relative efficiency from period 1 to period 2. Meanwhile the frontier shift effect measures the rate of technological change that is a combination of input and output from period 1 to period 2 . The frontier shift effect is often called an innovation effect.

The Malmquist index is a bilateral index used to compare production technologies of two economic elements. The Malmquist index is based on the concept of a production function that measures the maximum production function with defined input limits. In the calculation, this index consists of several results: efficiency change, technological change, pure efficiency change, economic scale change and TFP change.
The Malmquist index has some favorable characteristics. First, this index is a non-parametric method so it does not require specification of production function form. Secondly, the Malmquist index does not require the assumption of the economic behavior of production units such as cost minimization or profit maximization, so it is useful if the goals of the producers are different or unknown. Third, the calculation of this index does not require data prices that are often not available. Fourth, the Malmquist productivity index can be broken down into two components: efficiency change and technological change. According to Avenzora (2008) this is very useful because the analysis can be done more specifically by component.

In the first generation model developed by Caves et.al (1982), there are 2 (two) Malmquist productivity index models (Bjurek, 1996). The first is 'Malmquist input quantity index' and the second is 'Malmquist output quantity index'. Malmquist input quantity index for a production unit, at observation time $t$ and $t+$ 1 , for tech reference in period $\mathrm{k}, \mathrm{k}=\mathrm{t}$ and $\mathrm{t}$ + 1. The Malmquist input quantity index measures only the change in the quantity of inputs observed between time $\mathrm{t}$ and $\mathrm{t}+1$, where:

$$
\begin{aligned}
& M I_{k}\left(y_{k}, x_{t}, x_{t+1}\right)=\frac{E_{k}^{I}\left(y_{k}, x_{t}\right)}{E_{k}^{I}\left(y_{k}, x_{t+1}\right)}, k=t, \\
& t+1
\end{aligned}
$$

Next, for the Malmquist quantity output index for a production unit, at observation time $t$ and $t+1$, for tech reference in period $\mathrm{k}, \mathrm{k}=\mathrm{t}$ and $\mathrm{t}+1$. This Malmquist quantity output index measures only the change in the observed quantity of output between time $t$ and $t+1$, where: 
$M O_{k}\left(y_{t}, y_{t+1}, x_{k}\right)=\frac{E_{k}^{O}\left(y_{t+1}, x_{k}\right)}{E_{k}^{O}\left(y_{t}, x_{k}\right)}, k=t$, $t+1$

Bjurek (1996) introduces a new definition of the Malmquist productivity index for the production unit between $t$ and $t+1$ based on the technological level at $\mathrm{k}, \mathrm{k}=\mathrm{t}$ and $\mathrm{k}=\mathrm{t}+$ 1 , following the tradition of most productivity indices. Adjusting the Tornqvist productivity index, the index constructed is the ratio between an output index and an input index:

$$
\begin{aligned}
& \operatorname{MTFP} P_{k}=\frac{M O_{k}\left(y_{t}, y_{t+1}, x_{k}\right)}{M I_{k}\left(y_{k}, x_{t}, x_{t+1}\right)}= \\
& \frac{E_{k}^{O}\left(y_{t+1}, x_{k}\right) / E_{k}^{O}\left(y_{t}, x_{k}\right)}{E_{k}^{l}\left(y_{k}, x_{t}\right) / E_{k}^{l}\left(y_{k}, x_{t+1}\right)}, k=t, t+1
\end{aligned}
$$

The equation above illustrates the ratio between the output index and the Malmquist input index. If the value of the productivity index is greater than the number 1 , then there has been an increase in productivity. If the index value is less than 1 , the productivity level decreases, whereas if it equals 1 , the productivity level does not change.

Some research that applies zakat institution efficiency and productivity measurement with DEA and TFP change value for example done by Norazlina and Abdul Rahim (2012). They analyze the efficiency of zakat institutions in Malaysia by using data envelopment analysis (DEA) method to estimate zakat efficiency and Tobit model to determine the efficiency of zakat institution in Malaysia. Technical efficiency, pure technical efficiency and scale efficiency of DEA model being used. The empirical findings suggest that zakat payment, computerized zakat system, board size, audit committee and decentralization significantly affect the efficiency if zakat institutions in Malaysia. The analysis showed that fully corporatized zakat institutions are positively associated with efficiency of zakat institutions in Malaysia while partially corporatized negatively affect zakat efficiency.

Nur Hafizah and Selamah (2013) analyze the profile of zakat collection institutions and the efficiency of the institutions in collecting the zakat by using Data Envelopment Analysis (DEA) approach. The study conducted in the three states of Federal Territories including Kuala Lumpur, Putrajaya and Labuan. The results of the efficiency found that all of the three areas of zakat institutions are efficient. The overall finding indicate that the center managed by Federal Territories maintain their performance and able not only to increase the total of zakat collections but also number of new and existing zakat payers.

Other research done by Rusydiana \& Alparisi (2016). The study try to measure the efficiency of 3 (three) Zakat Institutions with Data Envelopment Analysis (DEA) method. Banxia Frontier Analyst 3.1 used in data calculation. The calculation of the level of OPZ efficiency in this study are relative, not absolute. The results show that there is 12 fully efficient Decision Making Unit (DMU) Zakat Institution (100\% efficient). Only 6 DMU inefficient. The main factor inefficiency Zakat Institution from 2007 to 2014 due to the distribution of zakat funds to ashnaf. It is still less than optimal. So it has not been able to resolve the problem of poverty.

\section{METHODOLOGY}

In this study, the estimated growth of TFP and its components refers to Malmquist Index and application of DEADual Programming method. The Malmquist TFP change index is formed from the value of efficiency change and technology change. Through the value of efficiency change will 
be known whether there is a change in the efficiency level from year to year. While technological change indicates whether there is a change of technical limit of efficiency from year to year. The malmquist TFP change is part of DEA method developed by Charnes Cooper Rhodes and Banker Charnes Cooper (Coelli et al, 1998, Coelli et al, 2005, Cooper et al, 2010). DEA is a mathematical programming technique that measure the efficiency and productivity of decision making unit or DMU to other similar DMU (Cooper et al, 2002). Early DEA and Malmquist TFP change are widely applied to the banking industry (Sherman \& Gold, 1985).

The productivity index is expressed by the TFP index of Malmquist over a given period. As the suggestion of Caves et.al (1982), this index is defined using a distance function that permits multi-input and multioutput use without the need to involve explicit price information. The function of this distance can be classified into a distance function oriented to the input and output. The input distance function seeks a minimal proportional expansion of input vectors for a constant output vector. In contrast, the output distance function seeks a minimum proportional expansion of the output vector for a constant input vector. The Malmquist TFP index measures TFP changes between two data points by computing the distance ratio for each data point, relative to the technological constraints.

The data used in this study are 4 zakat institutions from 2011 to 2016. The input and output variables are obtained from the financial statements of each zakat institutions. Two inputs and two outputs are used to measure the efficiency and productivity level of zakat institution. As input variables are Operational Costs (X1) and Personnel Costs (X2). Meanwhile, the output variables are Zakat Collection
Fund (Y1) and Zakat Disbursement Fund (Y2).

The analysis tools used in this research are Banxia Frontier Analyst 4 to measure the efficiency level of all zakat institutions DMUs during 2011-2016. To measure Malmquist's productivity index, the DEAP 2.1 software programme is used. Furthermore, to make the plot of zakat institutions group quadrant with 2 categories (change of efficiency and technological change) on $\mathrm{x}$ and $\mathrm{y}$ axis, SPSS 16 software is used as a tool. This classification based on Rusydiana \& Sanrego (2018), Rusydiana (2018) also Rusydiana \& Firmansyah (2017).

\section{RESULTS \& DISCUSSION}

\section{Quadrant Based on the MPI}

Zakat institutions are grouped into 4 (four) quadrants based on technical change level (TECH) categories and efficiency change (EFFCH) level categories, ie high and low. Quadrant 1 includes zakat institution which has technical change and highefficiency change, so it can be considered as a high-productivity zakat institution.

Table. 1 Malmquist Index Summary of Firm

\begin{tabular}{|l|l|l|l|l|l|}
\hline FIRM & effch & tech & pech & sech & tfpch \\
\hline$(1)$ & 1.000 & 1.229 & 1.000 & 1.000 & 1.229 \\
\hline$(2)$ & 0.974 & 1.068 & 1.000 & 0.974 & 1.040 \\
\hline$(3)$ & 1.029 & 1.154 & 1.000 & 1.029 & 1.188 \\
\hline$(4)$ & 0.927 & 1.101 & 1.030 & 0.900 & 1.021 \\
\hline Mean & 0.982 & 1.137 & 1.007 & 0.974 & 1.116 \\
\hline
\end{tabular}

$$
\begin{aligned}
& \text { Note: (1) Baznas, (2) LAZ PKPU, (3) } \\
& \text { LAZ DD, (4) LAZ RZI }
\end{aligned}
$$

On the other hand, Quadrant 4 is a group of zakat institution with low technical change and efficiency change. A collection of zakat 
institution in this group can be regarded as a zakat institution whose productivity progress is relatively stagnant due to the small value of TECH and EFFCH.

Quadrant 2 includes zakat institution that has a high technical change, but on the other hand has a low efficiency change. A collection of zakat institution in this group can be regarded as a zakat institution with low catching up ability. Increasing the number of DMUs of $i$ zakat institution in this 2 nd quadrant is a sign of ineffectiveness of zakat institution to produce efficiently (technical change and efficiency change rates are classified into high and low categories based on their mean values).

The quadrant 3 includes groups of zakat institution that have a low technical change, but on the other hand has a relatively high-efficiency change. The collection of zakat institution in quadrant 3 can be regarded as a zakat institution with low production technology improvement, but relatively able to achieve a high level of efficiency improvement.

Below is the zakat institution based on the calculation of Malmquist Productivity Index (MPI), with two categories namely technical change (TECH) on $\mathrm{Y}$ axis and efficiency change $(\mathrm{EFFCH})$ on $\mathrm{X}$ axis.

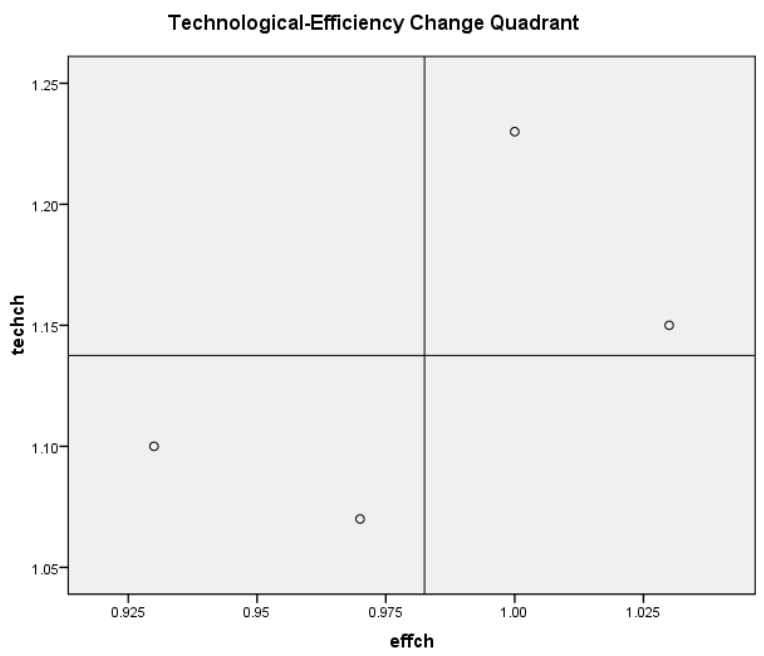

Picture 1. Zakat Institution Quadrants Based on the Malmquist Productivity Index
Information:

Q1 (High TECH, High EFFCH): Baznas $(1.000,1.229) \&$ DD $(1.029,1.154)$

Q2 (High TECH, Low EFFCH): No firm

Q3 (Low TECH, High EFFCH): No firm

Q4 (Low TECH, Low EFFCH): RZI (0.927, $1.101) \&$ PKPU $(0.974,1.068)$

In the picture 1 shows that in the study period 2011-2016, there are 2 zakat institution that is in quadrant 1 , there is no zakat institution that are in quadrant 2 , and quadrant 3. Meanwhile there are 2 zakat institution that enter the quadrant category 4.

Group quadrant 1 is a zakat institution category that has technical change and high-efficiency change. Zakat institution in this category are Badan amil zakat nasional (Baznas) and Dompet Dhuafa (DD). Baznas has a technical change value of 1.229, and an efficiency change of 1.000. Then, DD has a technical change value of 1.154, and an efficiency change of 1.029. Therefore, Baznas and DD are included in zakat institution with high productivity value.

Quadrant Group 2 is a zakat institution category that has a high technical change, but on the other hand has a low efficiency change. The collection of zakat institution in this group is considered a zakat institution with low catching up ability. Based on the results listed in the picture above, no zakat institution are included in this category.

Group quadrant 3 is a zakat institution category that has a low technical change, but on the other hand has a relatively high efficiency change. The zakat institution in quadrant 3 can be considered as a zakat institution with low production technology improvements, but are relatively capable of achieving a high level of efficiency. Same with quadrant 2, based on the results listed in the picture above, 
no zakat institution are included in this category.

The last quadrant is quadrant 4 is a group of zakat institution with technical change and low efficiency change. Zakat institution in this category are Rumah Zakat Indonesia (RZI) and Pos Keadilan Peduli Umat (PKPU). RZI has a technical change value of 1.101, and an efficiency change of 0.927. Then, PKPU has a technical change value of 1.068 , and an efficiency change of 0.974. The collection of zakat institution in this group can be considered as a zakat institution whose productivity progress is relatively stagnant.

The distribution of zakat institution in 4 (four) quadrants above can be influenced by the characteristics of the existing zakat institution in each group. Some variables that can describe the characteristics of each zakat institution such as product innovation, marketing strategy, location and network of zakat institution and types of ownership of the company. This figure is still indicative and requires formal testing, but is not covered in this study.

\section{Annual Productivity Index of Zakat Institution}

On table 2, it appears that for the duration of the 2011-2016 study, zakat institution in Indonesia show an improvement in productivity growth, as indicated by the value of $1.116 \mathrm{TFPCH}$. The increase in this TFPCH showed improvement levels of productivity in the zakat institutions in Indonesia. This is evidenced by the increase TECH above 1 (1.137), also PECH (1.007). In the other side, the changes in efficiency or EFFCH decreased below 1 (0.982) and SECH (0.974). It means, the increase in productivity levels of zakat institutions in Indonesia has been largely contributed by the high level of technological change (TECH) technological innovation and the stagnation of changes in its efficiency (EFFCH).

The lowest productivity decrease occurred in 2013-2014 and 2012-2013 with the value of TFPCH 0.733 and 0.957 . In general, the main factor inefficiency of Zakat Institution from 2007 to 2014 due to the distribution of zakat funds to ashnaf is still less optimal (Rusydiana \& Alparisi, 2016). In order efficient, inefficient zakat institution should reduce cost of human resources, socialization and operating costs. While for the revenue fund needs to be increased up to $0.93 \%$ and the fund distribution to $69 \%$ in order to achieve optimal efficiency levels.

Nevertheless, there are also conditions in which there is an increase in TFP productivity in zakat institutions in general. As happened in 2011-2012 (TFPCH $=1.680), 2015-2016(\mathrm{TFPCH}=1.296)$ and 2014-2015 intervals (TFPCH $=1.131)$. Beyond that, in general, the MPI rate of zakat institution in Indonesia has increased productivity levels that are marked by the change value of Total Factor Productivity or TFPCH above number 1 .

Table 2. Malmquist Index Summary of Annual Means

\begin{tabular}{|l|l|l|l|l|l|}
\hline PERIOD & effch & tech & pech & sech & tfpch \\
\hline $2011-2012$ & 0.865 & 1.942 & 1.093 & 0.791 & 1.680 \\
\hline $2012-2013$ & 0.915 & 1.046 & 0.950 & 0.963 & 0.957 \\
\hline $2013-2014$ & 1.202 & 0.610 & 1.021 & 1.177 & 0.733 \\
\hline $2014-2015$ & 1.015 & 1.114 & 1.042 & 0.974 & 1.131 \\
\hline $2015-2016$ & 0.944 & 1.373 & 0.939 & 1.005 & 1.296 \\
\hline Mean & 0.982 & 1.137 & 1.007 & 0.974 & 1.116 \\
\hline
\end{tabular}

\section{CONCLUSION}

This research tries to analyze BCC model as base model in DEA to see efficiency level of zakat institution in Indonesia for period 2011-2016. Further Malmquist index is used 
to see the productivity level of zakat institution, both in terms of changes in efficiency and technological change which is then displayed in the form of quadrant 4 groups.

The results obtained from the Malmquist index score (TFP Change) indicate that all of the zakat institution observed (4 institutions) has increased productivity. It is marked with a score of more than 1. This is evidenced by the increase TECH above 1 (1.137), also PECH (1.007). In the other side, the changes in efficiency or EFFCH decreased below 1 (0.982) and SECH (0.974). It means, the increase in productivity levels of zakat institutions in Indonesia has been largely contributed by the high level of technological change (TECH) technological innovation and the stagnation of changes in its efficiency (EFFCH).

For analysis of zakat institution group with efficiency change criterion $(\mathrm{EFFCH})$ and technological change (TECH), there are 2 zakat institution in quadrant 1 (technical change and high efficiency change), and 2 zakat institution in quadrant 4 (technical change and low efficiency change). Meanwhile, none of the zakat institution are in the quadrant category 2 (technical change high but low efficiency change) and 3 (technical change is low but high-efficiency change).

Calculation of the level of productivity in this study are relative, not absolute. So it is very possible when the sample of zakat institution added or time series of observation expanded, would get different results. The need for every Zakat Institution both public and private to issue annual financial statements in order to increase accountability and transparency in the management of funds. This financial statement data useful for researchers/ academics to be used as a source of research data. The ultimate goal is improvement and development of zakat and OPZ in Indonesia.

\section{REFERENCES}

Ahmad, Ismail HJ and Masturah Ma'in. 2014. "The Efficiency of Zakat Collection and Distribution: Evidence from Two Stage Analysis". Journal of Economic Cooperation and Development, 35, 3(2014) 133-170.

Akbar, Nasher. 2009. "Analisis Efisiensi Organisasi Pengelola Zakat Nasional Dengan Pendekatan Data Envelopment Analysis". Tazkia Islamic Finance and Business Review. Vol. 4 No. 2, 2009.

Avenzora Ahmad dan Jossy P. Moeis. (2008) "Analisis Produktivitas dan Efisiensi Industri Tekstil dan Produk Tekstil di Indonesia tahun 2002-2004. Disertasi pada FE Universitas Indonesia, Jakarta.

Banker, R.D., Charnes, A., and Cooper, W.W. (1984). "Some Models for Estimating Technical and Scale Inefficiency in Data Envelopment Analysis", Management Science, 30 (9), 1078-92.

Beik, Irfan Syauqi, et al. 2014. "Towardss an Establishment of an Efficient and Sound Zakat System: Proposed Core Principles for Effective Zakat Supervision. Paper presented in the Working Group of Zakat Core Principles 2014.

Bjurek, Hans. (1996). The malmquist total factor productivity index, The Scandinavian Journal of Economics, Vol. 98 (2).

Caves et.al. (1982). The Economic Theory of Index Number and The Measurement of Input, Output and Productivity. Econometrica, 50 (6). 
Charnes, A., Cooper, W.W., and Rhodes, E. (1978). "Measuring the Efficiency of Decision Making Units", European Journal of Operation Research, 2, 6, 429-44.

Coelli.T.I, Rao, D.S.P. and Battese, G.E. (1998). Introduction to Efficiency and Productivity Analysis, Boston: Kluwer Academic Publisher.

Coelli, T.J, Rao, D.S.P., Prasada Rao, Christoper J. O'Donnel and G.E. Battese. (2005). Introduction to Efficiency and Productivity Analysis, (Second Edition), Boston: Kluwer Academic Publishers.

Cooper, William W., Seiford, Lawrence M., and Tone, Koru. (1999). A Comprehensive Text with Models, Application, References and DEASolver Software, Boston: Kluwer Academic Publisher.

Cooper, et al. (2002). Data Envelopment Analysis. Boston: Kluwer Academic Publisher.

Cooper, William W, Lawrance M. Seiford and Joe Zhu. (2010). Handbook on Data Envelopment Analysis. London: Springer.

Farrell, M.L. (1957). "The Measurement of Productive Efficiency", Journal of The Royal Statistical Society, 120, p.253281.

Islamic Banker Association. (2017). Global Islamic Finance Report 2017.

Kamarudin. et.al. (2008). Assessing Production Efficiency of Islamic Banks and Conventional Bank Islamic Windows in Malaysia. International Journal of Business and Management Research. Vol. 1 (1):. 31-48. 2008.

Noor, Abd Halim Mohd, et al. 2012. "Assessing Performance of Nonprofit Organization: A Framework for Zakat Institutions". British Journal of Economics, Finance and Management Sciences, Vol. 5(1)
Noor, Abd Halim Mohd, et al. 2015. "Efficiency of Islamic Institutions: Empirical Evidence of Zakat Organizations Performance in Malaysia". Journal of Economics, Business and Management, Vol. 3 No.2.

Norazlina Abd Wahab, Abdul Rahim Abdul Rahman. 2011. "A Framework to Analyze the Efficiency and Governance of Zakat Institutions", Journal of Islamic Accounting and Business Research, Vol. 2 Iss 1, pp4362.

Norazlina Abd Wahab, Abdul Rahim Abdul Rahman. 2012. "Efficiency of Zakat Institutions in Malaysia: An Application of Data Envelopment Analysis", Journal of Economic Cooperation and Development, Vol. 33 No.1, pp 95-112.

Nurfalah, I., Rusydiana, A.S., Laila, N., and Cahyono, E.F. 2018, "Early warning to banking crises in the dual financial system in Indonesia: The markov switching approach", JKAU: Islamic Economics, Vol.31, No.2, pp.133-156.

Oscar, Yazar (2008), Health Care Benchmarking and Performance Evaluation: An Assessment using Data Envelopment Analysis. Springer, Newton MA.

Otoritas Jasa Keuangan. (2018). Statistik Perbankan Syariah Indonesia April Tahun 2018.

Ozdemir, Asli. 2013. "Integrating analytic network process and data envelopment analysis for efficiency measurement of Turkish commercial banks". Banks and Bank Systems Volume 8 issue 2, 2013.

Ramanathan, R. (2003). An Introduction to Data Envelopment Analysis: A Tool for Performance Measurement. London: Sage Publications. 
Rusydiana, Aam S., and Yulizar D. Sanrego, 2018. "Mesuring the performance of Islamic banking in Indonesia: An application of Maslahah efficiency quadrant (MEQ)". Journal of Monetary Economics and Finance, Vol 3 Special Issue, pp.103-130.

Rusydiana, Aam S., and Irman Firmansyah, 2017. "Efficiency versus Maqasid sharia index: An application on Indonesia Islamic bank". Shirkah Journal of Economics and Business, Vol 2 No 2, 2017.

Rusydiana, Aam S, and Salman Al Parisi, 2016. "The efficiency of zakah institution using data envelopment analysis". Al-Iqtishad: Jurnal Ilmu Ekonomi Syariah, Vol. 8, No. 2, pp.213-226.

Rusydiana, Aam S. 2018. "Indeks malmquist untuk pengukuran efisiensi dan produktivitas bank syariah di Indonesia", Jurnal Ekonomi dan Pembangunan LIPI, Vol.26, No.1, pp.47-58.

Rusydiana, A.S. dan Tim SMART Consulting. 2013. Mengukur Tingkat Efisiensi dengan Data Envelopment Analysis. Bogor: SMART Publishing.

Shahreki, Javad, Nazar Dahmardeh and Mohammad Ali Ghasemi. (2012). "Efficiency Evaluation Bank Sepah Branches in Sistan and Baluchestan Province Using Data Envelopment
Analysis". Interdisciplinary Journal of Contemporary Research in Business Vol. 4 No. 2, June 2012.

Tsolas, Ioannis E. and Dimitris I. Giokas. (2012). "Bank branch efficiency evaluation by means of least absolute deviations and DEA". Managerial Finance Vol 38 No. 8, 2012.

Wahab, Norazlina Abd. And Abdul Rahman, Abdul Rahim. 2012. "Efficiency of Zakat Institutions in Malaysia: An Application of Data Envelopment Analysis". Journal of Economic Cooperation and Development, 33, 1(2012) 95-112.

Wahab, Norazlina Abd. And Abdul Rahman, Abdul Rahim. 2013. "Determinants of Efficiency of Zakat Institutions in Malaysia: A Nonparametric Approach". Asian Journal of Business and Accounting, 6(2) 2013.

Aam Slamet Rusydiana

Shariah Economic Applied Research \& Training (SMART) Indonesia aamsmart@gmail.com

Tika Widiastuti

Airlangga University Surabaya Indonesia 